\title{
Energy Conservation in the Acetogenic Bacterium Clostridium aceticum
}

\author{
Anja Wiechmann and Volker Müller *
}

check for

updates

Citation: Wiechmann, A.; Müller, V. Energy Conservation in the Acetogenic Bacterium Clostridium aceticum. Microorganisms 2021, 9, 258. https://doi.org/10.3390/ microorganisms 9020258

Academic Editor: Françoise Bringel Received: 7 December 2020

Accepted: 20 January 2021

Published: 27 January 2021

Publisher's Note: MDPI stays neutral with regard to jurisdictional claims in published maps and institutional affiliations.

Copyright: (c) 2021 by the authors. Licensee MDPI, Basel, Switzerland. This article is an open access article distributed under the terms and conditions of the Creative Commons Attribution (CC BY) license (https:/ / creativecommons.org/licenses/by/ $4.0 /)$.

\author{
Molecular Microbiology and Bioenergetics, Institute of Molecular Biosciences, Johann Wolfgang Goethe \\ University Frankfurt, Max-von-Laue-Str. 9, 60438 Frankfurt am Main, Germany; \\ a.wiechmann@bio.uni-frankfurt.de \\ * Correspondence: vmueller@bio.uni-frankfurt.de; Tel.: +49-69-798-29507
}

\begin{abstract}
In times of global warming caused by the extensive use of fossil fuels, the need to capture gaseous carbon compounds is growing bigger. Several groups of microorganisms can fix the greenhouse gas $\mathrm{CO}_{2}$. Out of these, acetogenic bacteria are role models in their ability to reduce $\mathrm{CO}_{2}$ with hydrogen to acetate, which makes acetogens prime candidates for genetic modification towards biotechnological production of value-added compounds from $\mathrm{CO}_{2}$, such as biofuels. However, growth of acetogens on gaseous substrates is strongly energy-limited, and successful metabolic engineering requires a detailed knowledge of the bioenergetics. In 1939, Clostridium aceticum was the first acetogen to be described. A recent genomic study revealed that this organism contains cytochromes and therefore may use a proton gradient in its respiratory chain. We have followed up these studies and will present data that $C$. aceticum does not use a $\mathrm{H}^{+}$but a $\mathrm{Na}^{+}$gradient for ATP synthesis, established by a $\mathrm{Na}^{+}-\mathrm{Rnf}$. Experimental data and in silico analyses enabled us to propose the biochemistry and bioenergetics of acetogenesis from $\mathrm{H}_{2}+\mathrm{CO}_{2}$ in C. aceticum.
\end{abstract}

Keywords: energy conservation; respiratory chain; acetogenic bacteria; Wood-Ljungdahl pathway; ATP synthase; Rnf complex

\section{Introduction}

Acetogenic bacteria are a group of strictly anaerobic, facultative, chemolithoautotrophic bacteria [1]. During lithotrophic growth, $\mathrm{H}_{2}+\mathrm{CO}_{2}$ is converted to acetate by a specialized pathway, the Wood-Ljungdahl pathway (WLP) [2,3]. Out of the known $\mathrm{CO}_{2}$-fixation pathways, the WLP is the only one that does not require net input of ATP [4]. The two molecules of $\mathrm{CO}_{2}$ that are converted to acetate are reduced in two branches [3-6]. In the carbonyl branch, one $\mathrm{CO}_{2}$ is reduced to enzyme-bound carbon monoxide by $\mathrm{CO}$ dehydrogenase/acetyl-CoA synthase (CODH/ACS) [3,7]. In the methyl branch, $\mathrm{CO}_{2}$ is first reduced to formate, which is bound in a reaction driven by ATP hydrolysis to the $\mathrm{C} 1$ carrier tetrahydrofolate (THF) and then subsequently reduced via methenyl- and methyleneTHF to methyl-THF. The methyl group is then transferred by a methyltransferase to the $\mathrm{CODH} / \mathrm{ACS}$, where it condenses with enzyme-bound $\mathrm{CO}$ and $\mathrm{CoA}$ to acetyl-CoA which is further converted via acetyl-phosphate to acetate [8]. The last reaction regains the one mol of ATP invested in the second reaction and thus, the amount of ATP synthesized in this pathway is zero. Since the bacteria grow on $\mathrm{H}_{2}+\mathrm{CO}_{2}$ while producing acetate, the entire lithotrophic metabolism must be coupled to additional ATP synthesis [6].

In recent years it has been shown that acetogens use the electron transfer pathway to the WLP as the site of energy conservation by a chemiosmotic mechanism [6,9]. So far, two species have been investigated in detail. Thermoanerobacter kivui has a reduced ferredoxin: $\mathrm{H}^{+}$ oxidoreductase (Ech) [9] as a respiratory enzyme, whereas Acetobacterium woodii has a reduced ferredoxin:NAD ${ }^{+}$oxidoreductase (Rnf) as the one and only coupling site $[10,11]$. Both respiratory enzymes use the free energy change of electron transport to expel ions $\left(\mathrm{H}^{+} / \mathrm{Na}^{+}\right)$from the cytoplasm, thus establishing a transmembrane electrochemical ion 
gradient across the membrane that drives ATP synthesis via a membrane-bound $\mathrm{F}_{1} \mathrm{~F}_{\mathrm{O}}$ ATP synthase [12]. The fuel for the electron transport chain (reduced ferredoxin) is generated by electron bifurcation with hydrogen as reductant [13]. Every acetogen sequenced so far has either Rnf or Ech and at present, the presence of $e c h$ and $r n f$ genes are mutually exclusive with a prevalence for Ech in thermophilic species [9,14]. The situation is more complicated by the finding of cytochromes in some acetogens whose role in bioenergetics is poorly understood $[14,15]$. Nevertheless, the presence of cytochromes is indicative of proton-based bioenergetics. In 2015, the genome of the first isolated acetogen, Clostridium aceticum was sequenced [14]. As well as $r n f$ genes, cytochrome-encoding genes were found and therefore, C. aceticum was considered a missing link between Rnf and cytochromecontaining acetogens, although the same study questioned a role of cytochromes in the bioenergetics in C. aceticum. It was postulated, based on the genome sequence, that $C$. aceticum has a proton-based bioenergetic. We have checked this hypothesis by studying the core components of energy conservation and their ion-dependence. These studies revealed a $\mathrm{Na}^{+}$-dependent respiratory chain in C. aceticum with a $\mathrm{Na}^{+}$-dependent $\mathrm{Rnf}$ and ATP synthase.

\section{Materials and Methods}

\subsection{Conditions for Growth of C. aceticum}

C. aceticum (DSM1496) was grown under strictly anoxic conditions in medium described by Braun et al. (1981) and modified by Poehlein et al. (2015) [14,16]. Generally, cells were grown at $30^{\circ} \mathrm{C}$ in medium containing $20 \mathrm{mM}$ fructose, and a gas atmosphere that was changed from $\mathrm{N}_{2}+\mathrm{CO}_{2}(80: 20,[v / v])$ to $100 \% \mathrm{H}_{2}$ prior to inoculation, to increase the $\mathrm{pH}$ to around 8.4, due to the partial conversion of carbonate to $\mathrm{CO}_{2}$ in the liquid, which then diffuses into the headspace. For purification of the methylene-THF reductase cells were grown in a 20 L-flask (Glasgerätebau Ochs, Bovenden-Lenglern, Germany) on $20 \mathrm{mM}$ fructose without the addition of $\mathrm{H}_{2}$.

\subsection{Purification of Cytosol and Membranes from C. aceticum}

All steps were performed at room temperature under anoxic conditions in an anaerobic chamber (Coy Laboratory Products, Grass Lake, MI, USA) filled with $96 \% \mathrm{~N}_{2}$ and $4 \% \mathrm{H}_{2}$. For isolation of the cytosol of C. aceticum, cells were harvested and washed in buffer A ( $50 \mathrm{mM}$ Tris- $\mathrm{HCl}, 20 \mathrm{mM} \mathrm{MgSO}{ }_{4}, 2 \mathrm{mM}$ dithioerythritol (DTE), $4 \mu \mathrm{M}$ resazurin, $\mathrm{pH}$ 8). To disrupt the cells, cells were resuspended in buffer A containing $0.5 \mathrm{mM}$ phenylmethylsulfonyl fluoride (PMSF) and $0.1 \mathrm{mg} / \mathrm{mL}$ DNaseI, and were passed twice through a French pressure cell at $110 \mathrm{MPa}$. The same procedure was performed for isolation of membranes, with the only difference that buffer A was prepared with sodium-free chemicals. Cell debris together with membranes were then separated from the cytosolic fraction by ultracentrifugation at $130,000 \times g$ for $45 \mathrm{~min}$. The membrane fraction was resuspended in buffer $\mathrm{A}$, and as with the cytosolic fraction, it was stored in an anoxic tube at $4{ }^{\circ} \mathrm{C}$ until use.

\subsection{Purification of the Methylene-Tetrahydrofolate Reductase}

$77 \mathrm{~mL}$ of the cytosolic fraction $(60 \mathrm{mg} / \mathrm{mL}$ protein) from a $20 \mathrm{~L}$ culture were applied to a Q-Sepharose high-performance (HP) column (GE Healthcare, Chicago, IL, USA) equilibrated with buffer 1 ( $50 \mathrm{mM}$ Tris- $\mathrm{HCl}, 20 \mathrm{mM} \mathrm{MgSO}_{4}, 20 \%$ glycerol, $2 \mathrm{mM}$ DTE, $4 \mu \mathrm{M}$ resazurin, $\mathrm{pH}$ 7.6) using a flow rate of $2 \mathrm{~mL} / \mathrm{min}$. Protein was eluted with a linear gradient of $150 \mathrm{~mL}$ from 0 to $500 \mathrm{mM} \mathrm{NaCl}$ in buffer 1 . Methylene-THF-dependent oxidation of reduced methyl viologen was detected in the eluate containing around $150-220 \mathrm{mM}$ $\mathrm{NaCl}$. Ammonium sulfate $(2.4 \mathrm{M})$ was added to the pooled fractions $(13 \mathrm{~mL}, 15.5 \mathrm{mg} / \mathrm{mL}$ protein). The pool was loaded onto a Phenyl-Sepharose HP column (GE Healthcare, Chicago, IL, USA), equilibrated with buffer 1 containing $2.4 \mathrm{M}\left(\mathrm{NH}_{4}\right)_{2} \mathrm{SO}_{4}$ under a flow rate of $1.3 \mathrm{~mL} / \mathrm{min}$. Protein was eluted with a linear gradient of $200 \mathrm{~mL}$ from 2.4 to $0.0 \mathrm{M}$ $\left(\mathrm{NH}_{4}\right)_{2} \mathrm{SO}_{4}$. Methylene-THF-dependent oxidation of reduced methyl viologen eluted in a peak of around $480-160 \mathrm{mM}$ remaining $\left(\mathrm{NH}_{4}\right)_{2} \mathrm{SO}_{4}$. Pooled fractions were concentrated 
using ultrafiltration in 100-kDa Vivaspin tubes (Sartorius Stedim Biotech GmbH, Germany). The concentrated sample was separated on a HiPrep Sephacryl S-300 HR column (GE Healthcare, Chicago, IL, USA) equilibrated with buffer 1 containing $250 \mathrm{mM} \mathrm{NaCl}$ using a flow rate of $0.5 \mathrm{~mL} / \mathrm{min}$. Activity was found in fractions, which eluted after 20-30 mL.

\subsection{Measurement of Rnf Activity}

$\mathrm{Fd}_{\text {red }}: \mathrm{NAD}^{+}$oxidoreductase activity and its dependence on sodium ions was measured as described before [17]. Briefly, $1.8 \mathrm{~mL}$ anoxic cuvettes (Glasgerätebau Ochs, Bovenden, Germany) were filled with buffer ( $20 \mathrm{mM}$ Tris-HCl, $2 \mathrm{mM}$ DTE, $2.2 \mu \mathrm{M}$ resazurin, pH 7.7, contaminating $\mathrm{Na}^{+}$concentration $104 \mu \mathrm{M} \mathrm{Na}^{+}$) in an anaerobic chamber (Coy Laboratory Products, Grass Lake, MI, USA) filled with $96 \% \mathrm{~N}_{2}$ and $4 \% \mathrm{H}_{2}$ and sealed with rubber stoppers. Different amounts of $\mathrm{NaCl}, \mathrm{KCl}$, and $\mathrm{LiCl}$ were added and the head space of the cuvette was changed to CO. Reduction of $\mathrm{NAD}^{+}(3 \mathrm{mM})$ was monitored at $340 \mathrm{~nm}$ over time after addition of ferredoxin $(30 \mu \mathrm{M})$, purified from Clostridium pasteurianum [17] and $250 \mu \mathrm{g}$ of purified membrane. Ferredoxin was reduced by CODH/ACS, isolated from A. woodii as described by [17].

\subsection{Measurement of ATPase Activity}

ATPase activity was measured in buffer $(100 \mathrm{mM}$ Tris- $\mathrm{HCl}, 100 \mathrm{mM}$ maleic acid, $20 \mathrm{mM} \mathrm{NaCl}, 5 \mathrm{mM} \mathrm{MgCl} 2,10 \mu \mathrm{M} \mathrm{Na}^{+}$) at $30^{\circ} \mathrm{C}$. The $\mathrm{pH}$ was adjusted to 7.4 with $\mathrm{KOH}$. The sample was preincubated for $3 \mathrm{~min}$ at $30^{\circ} \mathrm{C}$ before addition of $3 \mathrm{mM}$ Tris-ATP to start the reaction. ATP-dependent formation of inorganic phosphate was followed as described by Heinonen and Lahti (1981) [18]. Samples were measured photometrically at $650 \mathrm{~nm}$.

\subsection{Measurements of Methylene-Tetrahydrofolate Reductase Activity}

Methylene-THF activity was measured photometrically at $604 \mathrm{~nm}$ under anoxic conditions in $1.8 \mathrm{~mL}$ anoxic cuvettes (Glasgerätebau Ochs, Bovenden, Germany) under a $\mathrm{N}_{2}$ atmosphere filled with buffer $\left(50 \mathrm{mM} \mathrm{KPO}_{4}, 5 \mathrm{mM} \mathrm{MgCl}_{2}, 2 \mathrm{mM}\right.$ DTE, $4 \mu \mathrm{M}$ resazurin, $\mathrm{pH}$ 7.5). The oxidation of $10 \mathrm{mM}$ methyl viologen (prereduced with sodium dithionite) was observed over time after addition of $1.5 \mathrm{mM}$ formaldehyde $+0.5 \mathrm{mM}$ tetrahydrofolate (THF) (Sigma-Aldrich, St. Louis, MO, USA), resulting in a racemic mixture containing $0.25 \mathrm{mM}$ methylene-THF $[19,20]$, and protein from the respective purification step of the methylene-THF reductase.

\subsection{Measurements of Methylene-Tetrahydrofolate Dehydrogenase Activity}

Methylene-THF dehydrogenase activity was measured photometrically at $340 \mathrm{~nm}$ under anoxic conditions in $1.8 \mathrm{ml}$ anoxic cuvettes (Glasgerätebau Ochs, Bovenden, Germany) under a $\mathrm{N}_{2}$ atmosphere filled with buffer (50 $\mathrm{mM} \mathrm{KPO}_{4}, 2 \mathrm{mM}$ DTE, $\mathrm{pH}$ 7.0) [21]. The reduction of $\mathrm{NAD}^{+}$was measured after addition of $1.5 \mathrm{mM}$ formaldehyde $+0.5 \mathrm{mM}$ THF (Sigma-Aldrich, St. Louis, MO, USA), resulting in a racemic mixture containing $0.25 \mathrm{mM}$ methylene-THF, and $30 \mu \mathrm{g}$ of cytosol from C. aceticum.

\subsection{Analytical Methods}

Soluble proteins were quantified using the method of Bradford (1976) [22], and membrane proteins by the method of Lowry et al. (1951) [23]. Proteins were separated in $12 \%$ SDS-polyacrylamide gels and stained with Coomassie Brilliant Blue. Native gel electrophoresis was performed as described before [24]. For genetic analyses, the Basic Local Alignment Search Tools (BLAST) from the National Center for Biotechnology Information (NCBI, Bethesda, MD, USA) was used. Sequence comparisons were performed with the Clustal Omega tool from the European Bioinformatics Institute (EMBL-EBI, Hinxton, UK). The sodium ion concentration was measured using a $\mathrm{Na}^{+}$specific electrode (Orion Star A214, Thermo Scientific, Waltham MA, USA). To reduce $\mathrm{Na}^{+}$contaminations, ultra-pure chemicals and buffer with low concentrations of ingredients were used. 


\section{Results}

\subsection{The Rnf Complex from C. aceticum Requires $\mathrm{Na}^{+}$for Activity}

C. aceticum contains six genes encoding an Rnf complex (CACET_c16320-CACET_c16 370 ), which are potentially organized in an operon (Figure 1). The order of the genes is identical to $A$. woodii and the number of nucleotides of the genes are roughly the same. The $\mathrm{RnfB}$ subunit can differ in length as shown for various organisms [25]; however, the RnfB of $A$. woodii and $\mathrm{RnfB}$ of $C$. aceticum have almost the same amount of amino acids (334 in A. woodii and 329 in C. aceticum) and show $51 \%$ homology. As in the RnfB of $A$. woodii, RnfB of $C$. aceticum possesses six predicted Fe-S centers. In C. aceticum, four of the Fe-S centers are coordinated by the motif C-X2-C-X2-C-X3-C-P and the two other centers are likely to be coordinated by $\mathrm{C}_{140}$ and $\mathrm{C}_{219}$.

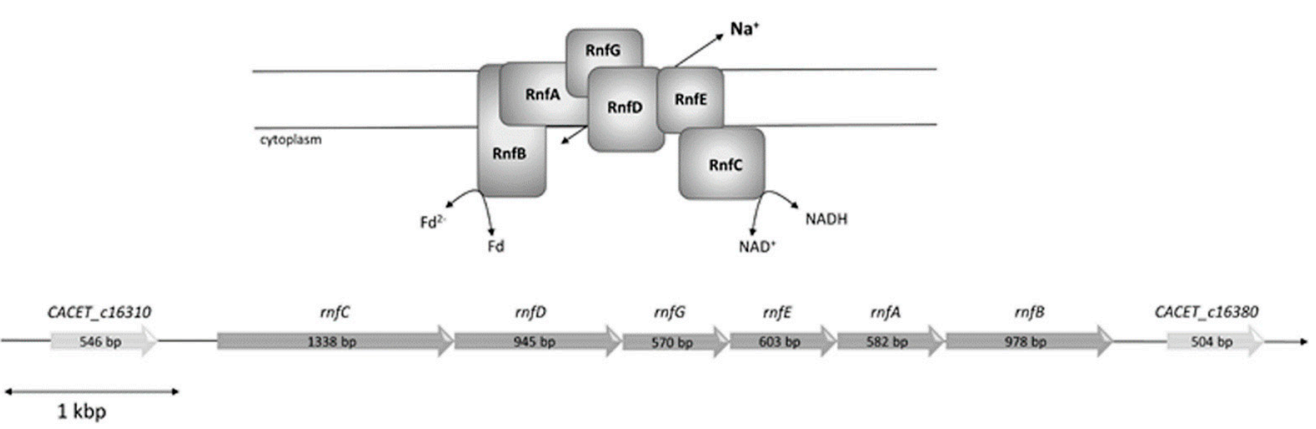

Figure 1. Model and genetic organization of the $r n f$ operon in C. aceticum. The $r n f$ genes are organized in a potential operon consisting of six genes, which code for a membrane-bound complex potentially consisting of monomers of each subunit. The first one is CACET_c16320 coding for RnfC, followed by CACET_c16330 coding for RnfD, CACET_c16340 coding for RnfG, CACET_c16350 coding for RnfE, CACET_c16360 coding for RnfA and CACET_c16370 coding for RnfB. The operon is flanked upstream by CACET_c16310, which has high similarity with an ATP-binding protein (sensor histidine kinase) and downstream by CACET_c16380, which has similarity with a transporter protein.

To determine whether the Rnf complex is indeed present, C. aceticum was grown on fructose and $\mathrm{H}_{2}+\mathrm{CO}_{2}$ in medium modified after Braun et al. (1981) [16] to the late exponential phase, harvested, and the cytoplasmic membrane was prepared. In order to measure ferredoxin: $\mathrm{NAD}^{+}$oxidoreductase activity we used ferredoxin isolated from $\mathrm{C}$. pasteurianum that was reduced by $\mathrm{CO}$, catalyzed by the $\mathrm{CODH}$ purified from $A$. woodii [17]. When membranes were incubated with $\mathrm{CODH}$, ferredoxin and $\mathrm{NAD}^{+}$under a $\mathrm{CO}$ atmosphere $\mathrm{NAD}^{+}$was reduced with a rate of $85.5 \pm 5.4 \mathrm{U} / \mathrm{mg}$. NAD ${ }^{+}$reduction strictly required $\mathrm{CO}, \mathrm{CODH}$, ferredoxin, membranes and $\mathrm{NAD}^{+}$. When no $\mathrm{NaCl}$ was added to the buffer, the contaminating $\mathrm{Na}^{+}$concentration was only $104 \mu \mathrm{M}$. Under these conditions, ferredoxin-dependent $\mathrm{NAD}^{+}$reduction was very low $(6.3 \pm 0.4 \mathrm{U} / \mathrm{mg})$. However, upon addition of $\mathrm{NaCl}$, activity was restored in a Michaelis-Menten-type fashion (Figure 2). Half maximal activity was obtained at around $5.6 \mathrm{mM} \mathrm{NaCl} . \mathrm{KCl}$ and $\mathrm{LiCl}$ did not stimulate ferredoxin:NAD ${ }^{+}$oxidoreductase activity (Figure 2). These data demonstrate that the Rnf complex of $C$. aceticum requires $\mathrm{Na}^{+}$for activity. 


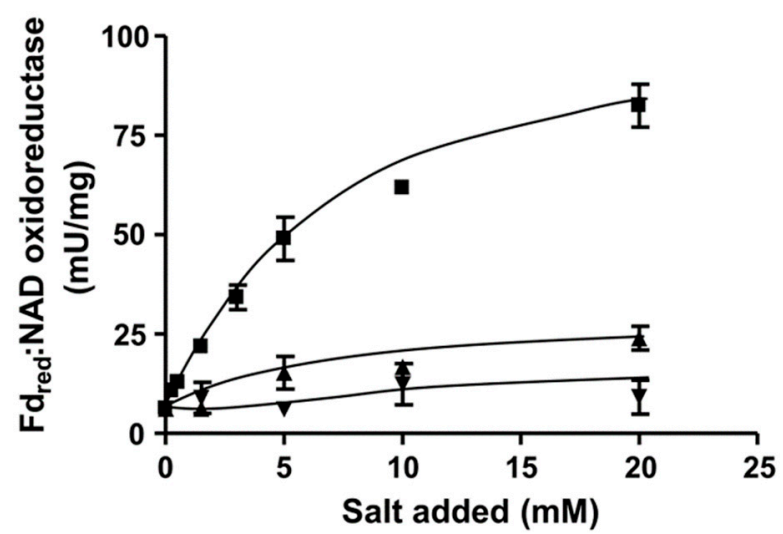

Figure 2. $\mathrm{Na}^{+}$dependence of ferredoxin:NAD ${ }^{+}$oxidoreductase (FNO) activity in C. aceticum. $250 \mu \mathrm{g}$ of purified membrane were added to $1 \mathrm{~mL}$ buffer $(20 \mathrm{mM}$ Tris- $\mathrm{HCl}, 2 \mathrm{mM}$ DTE, $2.2 \mu \mathrm{M}$ resazurin, $\mathrm{pH}$ 7.7) and FNO was measured as described in Materials and Methods. Increasing amounts $(0-20 \mathrm{mM})$ of $\mathrm{NaCl}(\boldsymbol{\nabla}), \mathrm{KCl}(\boldsymbol{\Delta})$ or $\mathrm{LiCl}(\boldsymbol{\nabla})$ were applied to the assays. The contaminating $\mathrm{Na}^{+}$ concentration was $104 \mu \mathrm{M}$. Results show data from two replicates.

\subsection{The ATP Synthase from C. aceticum Requires $\mathrm{Na}^{+}$for Activity}

The statement of Poehlein et al. (2015) [14] that the "ATPase from C. aceticum (encoded by CACET_c02130-CACET_c02220) does not contain an $\mathrm{Na}^{+}$-liganding amino acid motif", prompted us to reexamine the $c$ subunit composition of the ATP synthase from C. aceticum and its possible sodium ion dependence. The membrane-embedded rotor of $\mathrm{F}_{1} \mathrm{~F}_{\mathrm{O}}$-ATP synthases is usually made by multiple copies of one subunit, the rotor subunit $c$ [26]. This subunit is membrane-integral, has two transmembrane helices and harbors the ion binding site, which is either the so-called active carboxylate (Asp or Glu) that is protonated/deprotonated in $\mathrm{H}^{+}$ATPases or two more conserved residues, a glutamine in helix one and a serine/threonine in helix two, that together with the active carboxylate make the $\mathrm{Na}^{+}$binding site [12,27]. The operon structure of the ATP synthases of $A$. woodii (Awo_c02140-Awo_c02240) and C. aceticum (CACET_c02130-CACET_c02220) is conserved (Figure 3). C. aceticum has two copies of genes encoding the $c$ subunit of the ATP synthase (atpE1 and atpE2, annotated as CACET_c02150 and CACET_c02160, respectively) —atpE1 encodes subunit $c_{1}$ and atpE2 encodes subunit $c_{2}$. Like in $A$. woodii, subunit $c_{1}$ arose by duplication of an ancestral gene giving rise to a protein with four transmembrane helices [12] (Figure 4a). Hair pin one and hair pin two are 58\% identical on the amino acid level. Interestingly, like in A. woodii [28], the first hair pin has the conserved $\mathrm{Na}^{+}$binding site "Q....ET" but in the second hair pin, the gene duplication event resulted in the loss of the active carboxylate, rendering the resulting protein unable to bind either protons or sodium ions. Subunit $c_{1}$ is, therefore, similar to the $c$ subunit of eukaryotic ATPases that share the same feature $[29,30]$. Like in $A$. woodii but unlike most bacterial ATP synthases, there is a second gene encoding a $c$ subunit (CACET_c02160). Subunit $c_{2}$ is a "typical" bacterial $c$ subunit with two transmembrane helices, i.e., one hairpin. This subunit has the conserved $\mathrm{Na}^{+}$-binding motif "Q....ET" (Figure 4 b). A. woodii has a third gene, atpE3, that encodes a protein identical to subunit $c_{2}$ [31]; this gene is missing in C. aceticum. 


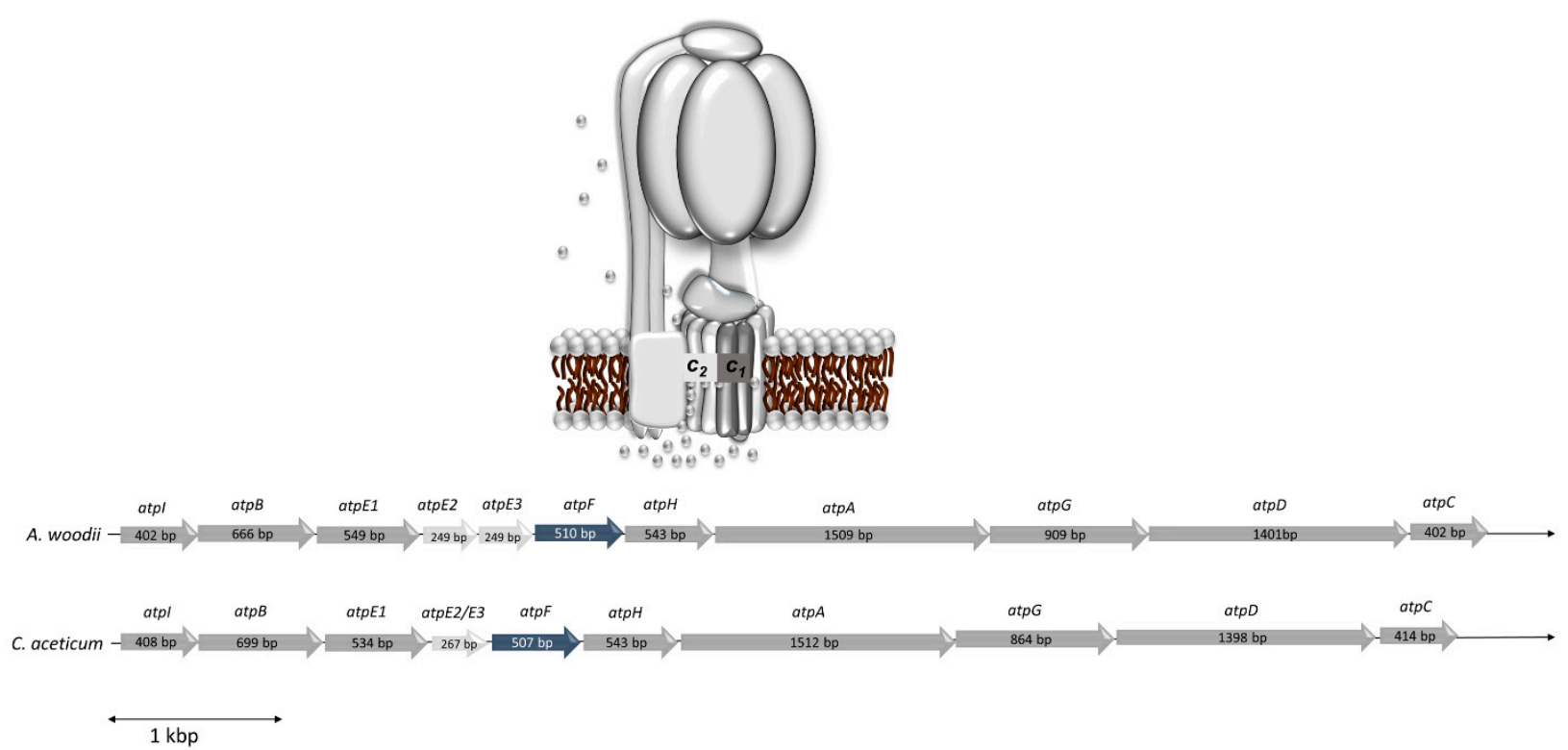

Figure 3. Model of the $\mathrm{Na}^{+} \mathrm{F}_{1} \mathrm{~F}_{\mathrm{O}}$ ATP synthase of $\mathrm{C}$. aceticum and comparison of the genetic organization of the atp operons of $A$. woodi and C. aceticum. The atp operon of $A$. woodii and $C$. aceticum coding for the $\mathrm{F}_{1} \mathrm{~F}_{\mathrm{O}}$-ATP synthase consists of 11 genes in A. woodii (Awo_c02140-Awo_c02240) and 10 genes in C.aceticum (CACET_c02130-CACET_c02220). The order of the genes is identical. C. aceticum misses atpE3, coding for subunit $c_{3}$, which is an exact copy of subunit $c_{2}$ in $A$. woodii. AtpI is not a subunit, but an assembly factor.

a

Alignment $c_{1}$ subunit (AtpE1)

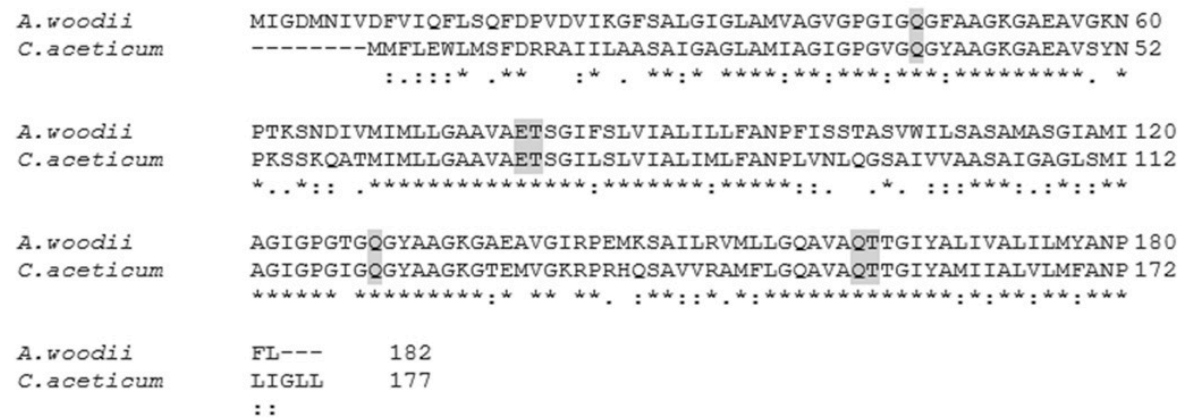

b

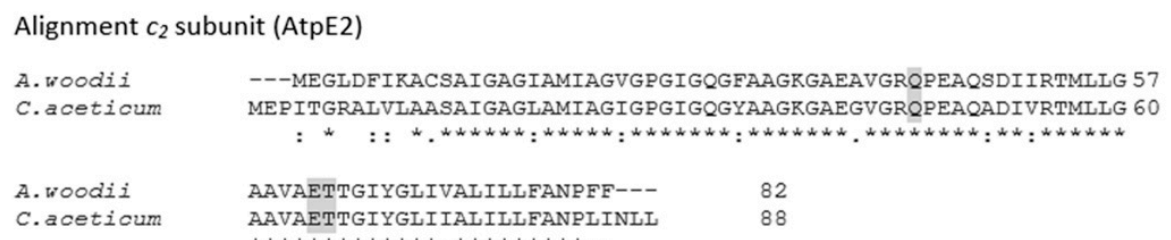

Figure 4. Alignment of the amino acids of subunits $c_{1}$ and $c_{2}$ of A. woodii and C. aceticum. Amino acids of the $c_{1}(\mathbf{a})$ and $c_{2}$ subunit (b), which are part of the $c$ ring of the ATP synthase from $A$. woodii and C. aceticum were aligned using Clustal Omega. Highlighted in grey are the $\mathrm{Na}^{+}$-binding motif Q....ET of one hairpin of the $c$ subunit and the second motif within a second hair pin without a functioning $\mathrm{Na}^{+}$-binding domain Q....QT.

The presence of a sodium ion binding site prompted us to examine the effect of $\mathrm{Na}^{+}$ on ATP hydrolysis. Therefore, membranes were prepared as described above and assayed for ATP hydrolysis. As can be seen from Figure 5, ATPase activity was already $20 \mathrm{mU} / \mu \mathrm{g}$ 
in the presence of contaminating $\mathrm{Na}^{+}$concentrations. This is in contrast to the $\mathrm{Na}^{+}-\mathrm{Rnf}$. For the latter, there are few data available with respect to the ion dependence and so far, it has not been addressed whether a $\mathrm{Na}^{+}-\mathrm{Rnf}$ can translocate $\mathrm{H}^{+}$in the absence of $\mathrm{Na}^{+}$. This is different in ATP synthases. Every $\mathrm{Na}^{+}$ATP synthase examined to date can translocate $\mathrm{H}^{+}[32,33]$. However, since at physiological conditions the $\mathrm{Na}^{+}$concentration is much higher (mM range) than the $\mathrm{H}^{+}$concentration $\left(10^{-4} \mathrm{mM}\right.$ at $\left.\mathrm{pH} 7.0\right)$, the coupling ion under physiological conditions is $\mathrm{Na}^{+}$[33]. Activity of the enzymes is not strictly dependent on $\mathrm{Na}^{+}$(depending on the affinities of these enzymes to $\mathrm{Na}^{+}$and $\mathrm{H}^{+}$, which is different in different enzymes) but stimulated by $\mathrm{Na}^{+}$. This is also observed for ATP hydrolysis here. Activity was not stimulated by $\mathrm{KCl}$ but by $\mathrm{NaCl}$ to around $200 \%$. The dependence of ATP hydrolysis on $\mathrm{NaCl}$ followed a Michaelis-Menten kinetic with half maximal activity at around $0.06 \mathrm{mM} \mathrm{NaCl}$. The $\mathrm{Na}^{+}$ATP synthases can also translocate $\mathrm{Li}^{+}$but have a weaker affinity to $\mathrm{Li}^{+}$[32]. The same is observed here- $-\mathrm{Li}^{+}$also stimulated, but stimulation was reduced.

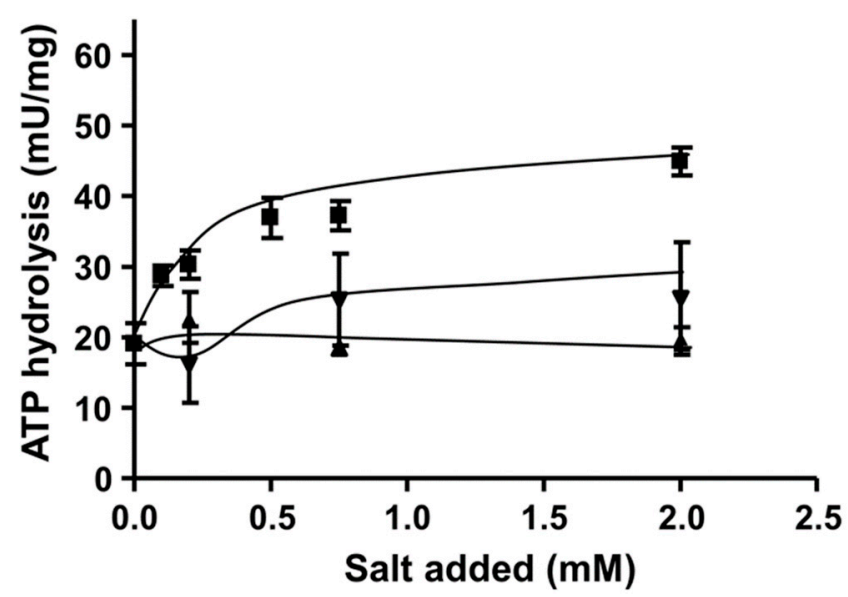

Figure 5. Sodium ion dependence of ATP hydrolysis activity in C. aceticum. $135 \mu \mathrm{g}$ of purified membranes were added to $1200 \mu \mathrm{L}$ ATPase buffer (100 mM Tris-HCl, $100 \mathrm{mM}$ malic acid, pH 7.4) containing $\mathrm{NaCl}(\boldsymbol{\square}), \mathrm{KCl}(\boldsymbol{\Delta})$ or $\mathrm{LiCl}(\boldsymbol{\nabla})$. The sample was incubated for $3 \mathrm{~min}$ at $30^{\circ} \mathrm{C}$. The reaction was started by adding $3 \mathrm{mM}$ Tris-ATP. The contaminating $\mathrm{Na}^{+}$concentration was $10 \mu \mathrm{M}$. Results show data from two replicates.

\subsection{The Methylene-THF Reductase Is of the MetF/MetV-Type}

The methylene-THF reductase catalyzes the most exergonic reaction of the pathway and was, therefore, suggested some 40 years ago to be involved in energy conservation [34]. Although it was speculated some time ago that the methylene-THF reductase is the acceptor of a membrane-bound electron transport chain [35], this hypothesis has been clearly excluded by experimental data for the model acetogens analyzed [21]. However, the methylene-THF reductase may be a site for electron-bifurcation with ferredoxin as electron acceptor [36], thus providing additional fuel for the electron transport chain. This has been clearly excluded for $A$. woodii [21] but hypothesized for Moorella thermoacetica [37]. The A. woodii enzyme has the typical subunits MetF and MetV, but one additional subunit, $\mathrm{RnfC} 2$. The latter provides the NADH binding site and catalyzes NADH oxidation with the electron passing on to methylene-THF via MetF and MetV [21]. M. thermoacetica only has met $V / m e t F$ genes but upstream genes are found that encode proteins with similarity to $\mathrm{HdrC}, \mathrm{HdrB}, \mathrm{HdrA}$, and MvhD. Since these are known from electron bifurcating proteins, the idea arose that MetV / F form a complex with HdrCBA and MvhD to bifurcate electrons from NADH to methylene-THF and an unknown acceptor [37]. In contrast, C. aceticum has only the metF/ $V$ genes. To analyze the subunit composition and function of the methylene-THF reductase from $C$. aceticum, it was enriched by three consecutive chromatography steps from a cell-free extract of $C$. aceticum grown on fructose. As can be seen in Figure 6a, MetF and MetV with apparent molecular masses of 23 and $32 \mathrm{kDa}$ 
were clearly visible. In addition, some minor contaminations were also visible. In a native PAGE, complexes of around 55 and around $75 \mathrm{kDa}$ were visible indicating a stoichiometry of MetF and MetV of 1:1 (Figure 6b) or 2:1. The determination of the exact stoichiometry requires additional experiments and, most important, a purified enzyme. Interaction of MetF/MetV with EtfAB or other potential bifurcating subunits was not observed. The enriched MetF/MetV preparation used neither NADH nor NADPH as electron donor for methylene-THF reduction, even in the presence of ferredoxin. The only activity that could be determined was methylene-THF-dependent methylviologen oxidation (around $400 \mathrm{U} / \mathrm{mg})$.
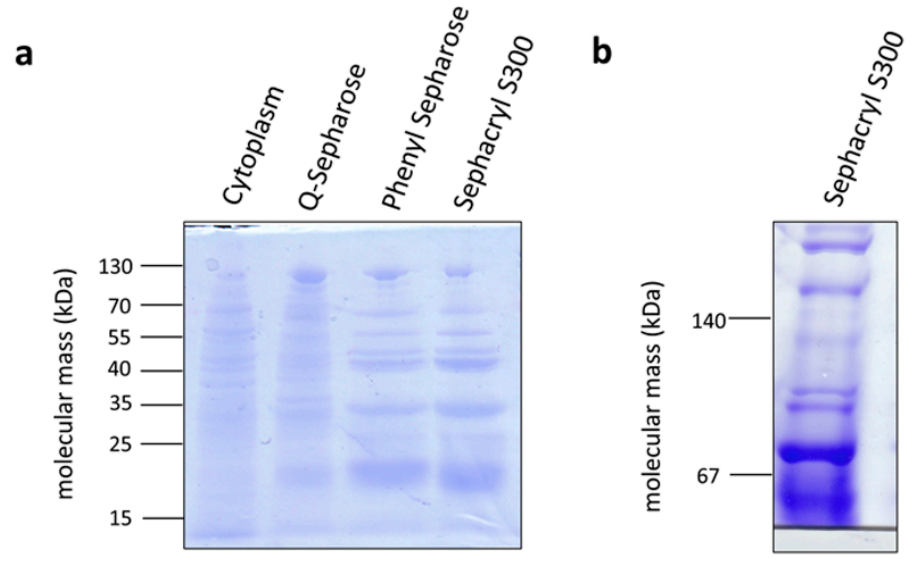

Figure 6. Enrichment of the methylene-THF reductase from C. aceticum. Samples (10 $\mu \mathrm{g}$ protein) of the cytoplasm and the purification fractions of the Q-sepharose, phenyl sepharose, and the sephacryl S300 column were separated via SDS PAGE (a). $10 \mu \mathrm{g}$ of pooled active fractions of the sephacryl S300 column were also separated on a native PAGE (b). Gels were stained with Coomassie Brilliant Blue.

\subsection{The Methylene-THF Dehydrogenase Is NAD Dependent}

Another important question for the overall bioenergetics is whether the methyleneTHF dehydrogenase is NAD- or NADP-specific. To address this question, cells were grown on fructose and $\mathrm{H}_{2}+\mathrm{CO}_{2}$, harvested in late exponential growth phase and a cell-free extract was prepared. This extract catalyzed methylene-THF oxidation with $\mathrm{NAD}^{+}(6.3 \pm 1 \mathrm{U} / \mathrm{mg})$ but not with $\mathrm{NADP}^{+}$(data not shown) as electron acceptor.

\subsection{C. aceticum Has an Electron-Bifurcating Formate Dehydrogenase}

As suggested by Poehlein et al. (2015), C. aceticum contains two potential genes coding for formate dehydrogenases: CACET_c32690 and CACET_c07250. The latter is potentially misannotated. The genetic organization and similarity analyses suggests that it is homologous to a subunit of the recently described novel NADH-dependent NADPH:ferredoxin oxidoreductase (Stn) from Sporomusa ovata (SOV_1c07740-SOV_1c07760) [38] that is also present in C. aceticum (CACET_c07230-CACET_c07250). The operon containing CACET_c3 $2690(f d h A)$ encodes a selenocysteine-containing formate dehydrogenase with $44 \%$ homology to FdhF1/2 from A. woodii. Unlike A. woodii and Gottschalkia acidurici, C. aceticum has only the selenocysteine-containing formate dehydrogenase. Upstream of $f d h A$ are genes encoding proteins with similarity to subunits of the electron-bifurcating formate dehydrogenase from G. acidurici. FdhA, HdB, and $\mathrm{HydC}$ are highly similar to the homologous protein from G. acidurici (with 60\%-70\% identity) [39]. However, compared to G. acidurici, C. aceticum does not possess a gene coding for HylA but HylA has similarity (47\%) to the N-terminus of FdhA of C. aceticum. Interestingly, genes encoding HydB and HydD occur twice in the operon of $C$. aceticum (Figure 7). The overall similarity of the genetic organization and the gene products suggests that C. aceticum has an electron-bifurcating formate dehydrogenase complex that, like G. acidurici, catalyzes the reduction of formate with simultaneous oxidation of reduced ferredoxin and NADH. 
Gottschalkia acidurici

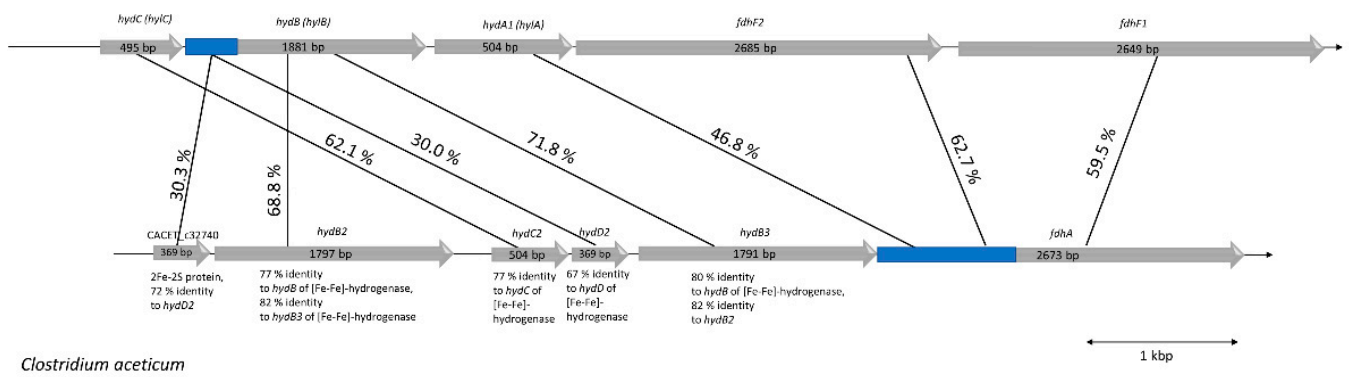

Figure 7. Genetic organization of the potential formate dehydrogenase (fdh) gene cluster in C. aceticum compared to the $f d h$ gene cluster of G. acidurici. Genes coding for a potential electron-bifurcating formate dehydrogenase in C. aceticum are organized in a cluster consisting of six genes, whereas in G. acidurici there are only five [39]. The first one is CACET_c32740 coding for a $2 \mathrm{Fe}-2 \mathrm{~S}$ protein (HydD3), which has $72 \%$ similarity to HydD2, another protein encoded in the $f d h$ operon (CACET_c32710). Both genes are not found in the $f d h$ gene cluster of G. acidurici, but they are both similar (around 30\%) to the first 180 amino acids of HylB (encoded by Curi_c29400). HydB2 (encoded by CACET_c32730) and HydB3 (encoded by CACET_c32700) in C. aceticum share $82 \%$ identity and are both similar to HylB of G. acidurici. HydC2 (encoded by CACET_c32720) of C. aceticum is 62\% similar to HylC of G. acidurici (Curi_c29410). In contrast to G. acidurici, which has two fdhF genes (Curi_29370 and Curi_29380), C. aceticum possesses only one gene (CACET_c32690) coding for a formate dehydrogenase (FdhA), which is around $60 \%$ homologous to both FdhFs of G. acidurici. The fdh gene cluster of C. aceticum is flanked upstream by CACET_c32750, which has similarity with a HPr kinase (a phosphocarrier protein of the phosphoenolpyruvate-dependent sugar phosphotransferase system) and downstream by CACET_c32680, which has similarity with a rubredoxin.

\section{Discussion}

The data presented here demonstrate that $C$. aceticum has a sodium ion-dependent respiratory chain with a $\mathrm{Na}^{+}-\mathrm{Rnf}$ and a $\mathrm{Na}^{+}-\mathrm{F}_{1} \mathrm{~F}_{\mathrm{O}}-\mathrm{ATP}$ synthase. The latter has, like the enzyme from $A$. woodii [29], a typical V-type ATPase $c$ subunit $\left(c_{1}\right)$ and thus, like $A$. woodii, a reduced $\mathrm{Na}^{+}$to ATP stoichiometry, which is seen as an adaptation to low-energy environments [40-42]. Unlike $A$. woodii, which has two identical F-type ATP synthase $c$ subunits [31], C. aceticum has only one. For the future, it would be interesting to determine the number of the different subunits in the $c$ ring.

The methylene-THF reductase has only two subunits, MetF and MetV, as evident after enrichment of the enzyme and as suggested from the genomic organization. NADH was not used as electron donor, neither was NADPH. As in every other case of MetF/MetV-type methylene-THF reductases known to date, the physiological electron donor is unknown and it remains elusive whether or not the enzyme uses a second, low-potential electron acceptor that is reduced by electron bifurcation. Loss of loosely attached subunits cannot be excluded but is unlikely since also the cell-free extract did not catalyze NAD $(P) H$ dependent methylene-THF reduction. For our model, we assume electron bifurcation with an unknown low-potential electron acceptor. The formate dehydrogenase is suggested to be electron-bifurcating, like the homologous enzyme from G. acidurici [39] with NADH and reduced ferredoxin as reductant. An electron-bifurcating FeFe-hydrogenase as in A. woodii was described before in C. aceticum [14]. In sum, the data presented allowed us to depict a model for the biochemistry and bioenergetics of acetogenesis from $\mathrm{H}_{2}+\mathrm{CO}_{2}$ in C. aceticum. It should be noted, that, in contrast to other acetogens, electron bifurcation in the course of methylene-THF reduction is not mandatory. Even without an electronbifurcating methylene-THF reductase, the redox balance is even and under these conditions, 0.3 mol of ATP are synthesized per mol of acetate (Figure 8a) (assuming the same $\mathrm{Na}^{+} /$ATP stoichiometry for the ATP synthase as in A. woodii). 

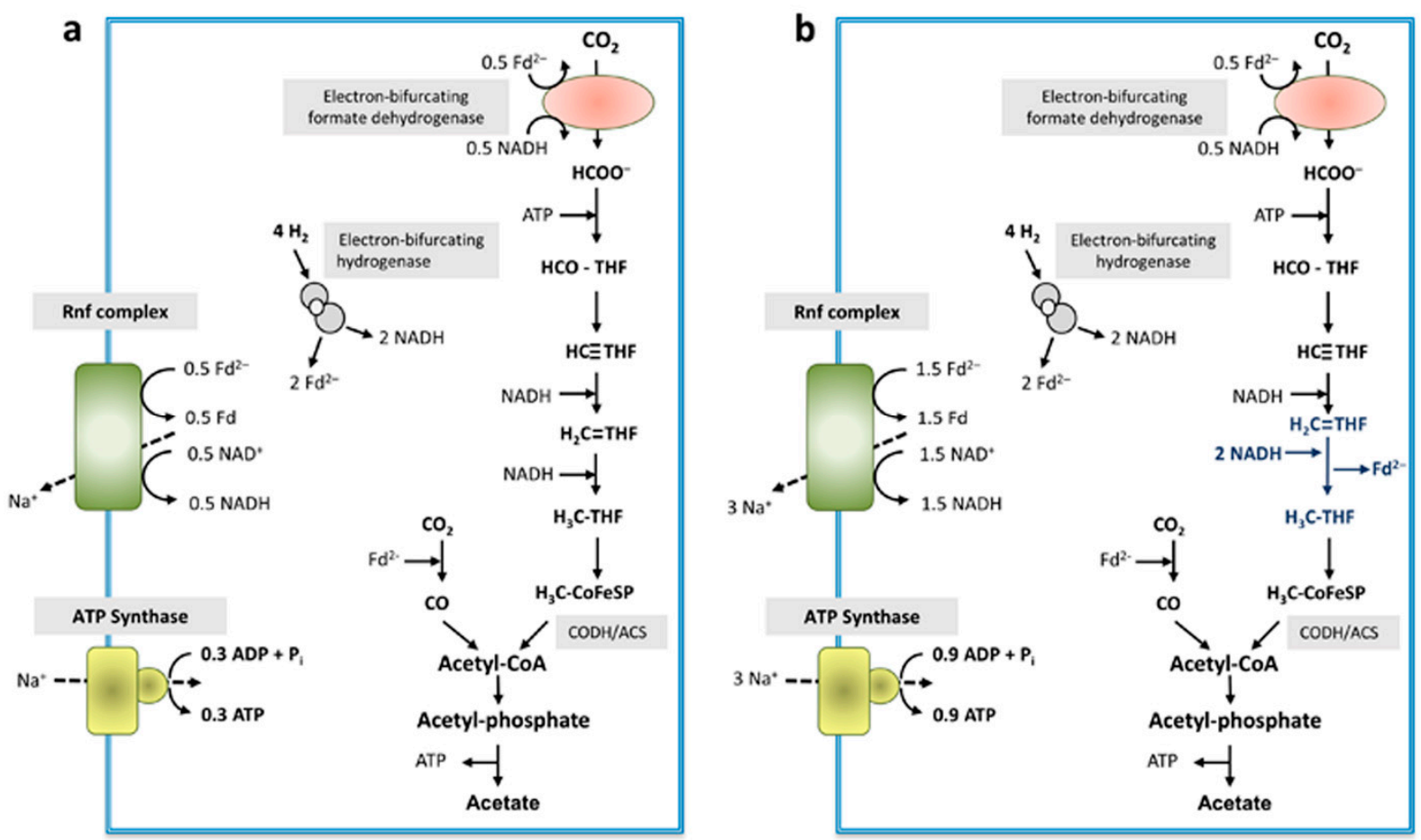

Figure 8. Schematic overview of energy conservation during acetogenesis from $\mathrm{H}_{2}+\mathrm{CO}_{2}$ in C. aceticum. The electronbifurcating hydrogenase converted $4 \mathrm{~mol}$ of $\mathrm{H}_{2}$ to 2 mol reduced ferredoxin and 2 mol NADH. Then, 0.5 mol of reduced ferredoxin together with $0.5 \mathrm{~mol} \mathrm{NADH}$ are used by the electron-bifurcating formate dehydrogenase to reduce $1 \mathrm{~mol}$ of $\mathrm{CO}_{2}$ to formate. Formate gets further reduced to methyl-THF via several reduction steps: if the methylene-THF reductase uses only NADH as reductant (a), 2 mol NADH are required to reduce methenyl-THF to methyl-THF, whereas 3 mol NADH would be required if the methylene-THF reductase is electron bifurcating $(\mathbf{b})$, which leads to the reduction of another mol of ferredoxin. After condensation of methyl-THF and $1 \mathrm{~mol} \mathrm{CO}_{2}$ by the CODH/ACS, acetyl-CoA is further converted to acetate. For energy conservation the Rnf complex in concert with the ATP synthase are used. A Na ${ }^{+}$ATP stoichiometry of 3.3 as in A. woodii [43] is assumed. Depending on the mode of operation of the methylene-THF reductase, either 0.3 or 0.9 mol ATP can be generated. Fd, ferredoxin; THF, tetrahydrofolate; CoFeSP, corrinoid iron-sulfur protein.

However, the redox balance is also even if an electron-bifurcating methylene-THF reductase is assumed (Figure $8 \mathrm{~b}$ ). In this model, the ATP gain is increased by $200 \%$ to $0.9 \mathrm{ATP} /$ acetate.

Author Contributions: Conceptualization, A.W, V.M.; Funding acquisition, V.M.; Investigation, A.W.; Visualization, A.W.; Writing-original draft, A.W., V.M. All authors have read and agreed to the published version of the manuscript.

Funding: This work was funded by financial support from the BMBF (Federal Ministry of Education and Research) ERA-IB: OBAC project, grant number ERA-IB-16-018.

Institutional Review Board Statement: Not applicable.

Informed Consent Statement: Not applicable.

Data Availability Statement: The data presented in this study are available on request from the corresponding author.

Conflicts of Interest: The authors declare no conflicts of interest.

\section{References}

1. Drake, H.L. Acetogenesis, Acetogenic Bacteria, and the Acetyl-CoA “Wood/Ljungdahl” Pathway: Past and Current Perspectives. In Acetogenesis; Drake, H.L., Ed.; Springer: New York, NY, USA, 1994; pp. 3-60.

2. Ljungdahl, L.G. The Acetyl-CoA Pathway and the Chemiosmotic Generation of ATP during Acetogenesis. In Acetogenesis; Drake, H.L., Ed.; Chapman \& Hall: New York, NY, USA, 1994; pp. 63-87. 
3. Ragsdale, S.W.; Pierce, E. Acetogenesis and the Wood-Ljungdahl Pathway of $\mathrm{CO}_{2}$ fixation. Biochim. Biophys. Acta (BBA) Proteins Proteom. 2008, 1784, 1873-1898. [CrossRef]

4. Fuchs, G. Alternative Pathways of Carbon Dioxide Fixation: Insights into the Early Evolution of Life? Annu. Rev. Microbiol. 2011, 65, 631-658. [CrossRef] [PubMed]

5. Ljungdahl, L.G. The Autotrophic Pathway of Acetate Synthesis in Acetogenic Bacteria. Annu. Rev. Microbiol. 1986, 40, 415-450. [CrossRef] [PubMed]

6. Schuchmann, K.; Müller, V. Autotrophy at the thermodynamic limit of life: A model for energy conservation in acetogenic bacteria. Nat. Rev. Microbiol. 2014, 12, 809-821. [CrossRef] [PubMed]

7. Drake, H.L.; Gößner, A.S.; Daniel, S.L. Old Acetogens, New Light. Ann. N. Y. Acad. Sci. 2008, 1125, 100-128. [CrossRef] [PubMed]

8. Ragsdale, S.W. Enzymology of the Wood-Ljungdahl Pathway of Acetogenesis. Ann. N. Y. Acad. Sci. 2008, 1125, 129-136. [CrossRef] [PubMed]

9. Schoelmerich, M.C.; Müller, V. Energy-converting hydrogenases: The link between $\mathrm{H}_{2}$ metabolism and energy conservation. Cell. Mol. Life Sci. 2020, 77, 1461-1481. [CrossRef]

10. Biegel, E.; Müller, V. Bacterial $\mathrm{Na}^{+}$-translocating ferredoxin:NAD ${ }^{+}$oxidoreductase. Proc. Natl. Acad. Sci. USA 2010, 107, 18138-18142. [CrossRef]

11. Biegel, E.; Schmidt, S.; González, J.M.; Müller, V. Biochemistry, evolution and physiological function of the Rnf complex, a novel ion-motive electron transport complex in prokaryotes. Cell. Mol. Life Sci. 2011, 68, 613-634. [CrossRef]

12. Brandt, K.; Müller, V. Hybrid rotors in $\mathrm{F}_{1} \mathrm{~F}_{\mathrm{o}}$ ATP synthases: Subunit composition, distribution, and physiological significance. Biol. Chem. 2015, 396, 1031-1042. [CrossRef]

13. Schuchmann, K.; Müller, V. A Bacterial Electron bifurcating Hydrogenase. J. Biol. Chem. 2012, 287, 31165-31171. [CrossRef] [PubMed]

14. Poehlein, A.; Cebulla, M.; Ilg, M.M.; Bengelsdorf, F.R.; Schiel-Bengelsdorf, B.; Whited, G.; Andreesen, J.R.; Gottschalk, G.; Daniel, R.; Dürre, P. The Complete Genome Sequence of Clostridium aceticum: A missing link between Rnf- and cytochrome-containing autotrophic acetogens. mBio 2015, 6, e01168-15. [CrossRef] [PubMed]

15. Pierce, E.; Xie, G.; Barabote, R.D.; Saunders, E.; Han, C.S.; Detter, J.C.; Richardson, P.; Brettin, T.S.; Das, A.; Ljungdahl, L.G.; et al. The complete genome sequence of Moorella thermoacetica (f. Clostridium thermoaceticum). Environ. Microbiol. 2008, 10, $2550-2573$. [CrossRef]

16. Braun, M.; Mayer, F.; Gottschalk, G. Clostridium aceticum (Wieringa), a microorganism producing acetic acid from molecular hydrogen and carbon dioxide. Arch. Microbiol. 1981, 128, 288-293. [CrossRef] [PubMed]

17. Hess, V.; Schuchmann, K.; Müller, V. The Ferredoxin:NAD ${ }^{+}$Oxidoreductase (Rnf) from the Acetogen Acetobacterium woodii Requires $\mathrm{Na}^{+}$and is Reversibly Coupled to the Membrane Potential. J. Biol. Chem. 2013, 288, 31496-31502. [CrossRef]

18. Heinonen, J.E.; Lahti, R.J. A new and convenient colorimetric determination of inorganic orthophosphate and its application to the assay of inorganic pyrophosphatase. Anal. Biochem. 1981, 113, 313-317. [CrossRef]

19. Wohlfarth, G.; Diekert, G. Thermodynamics of methylenetetrahydrofolate reduction to methyltetrahydrofolate and its implications for the energy metabolism of homoacetogenic bacteria. Arch. Microbiol. 1991, 155, 378-381. [CrossRef]

20. Sheppard, C.A.; Trimmer, E.E.; Matthews, R.G. Purification and Properties of NADH-Dependent 5, 10-methylenetetrahydrofolate Reductase (MetF) from Escherichia coli. J. Bacteriol. 1999, 181, 718-725. [CrossRef]

21. Bertsch, J.; Öppinger, C.; Hess, V.; Langer, J.D.; Müller, V. A Heterotrimeric NADH-Oxidizing Methylenetetrahydrofolate Reductase from the Acetogenic Bacterium Acetobacterium woodii. J. Bacteriol. 2015, 197, 1681-1689. [CrossRef]

22. Bradford, M.M. A rapid and sensitive method for the quantification of microgram quantities of protein utilizing the principle of proteine-dye-binding. Anal. Biochem. 1976, 72, 248-254. [CrossRef]

23. Lowry, O.H.; Rosebrough, N.J.; Farr, A.L.; Randall, R.J. Protein measurement with the Folin-phenol reagent. J. Biol. Chem. 1951, 193, 265-275. [CrossRef]

24. Wittig, I.; Carrozzo, R.; Santorelli, F.M.; Schägger, H. Functional assays in high-resolution clear native gels to quantify mitochondrial complexes in human biopsies and cell lines. Electrophoresis 2007, 28, 3811-3820. [CrossRef] [PubMed]

25. Kuhns, M.; Trifunović, D.; Huber, H.; Müller, V. The Rnf complex is a $\mathrm{Na}^{+}$coupled respiratory enzyme in a fermenting bacterium, Thermotoga maritima. Commun. Biol. 2020, 3, 1-10. [CrossRef]

26. Müller, V.; Grüber, G. ATP synthases: Structure, function and evolution of unique energy converters. Cell. Mol. Life Sci. 2003, 60, 474-494. [CrossRef] [PubMed]

27. Rahlfs, S.; Müller, V. Sequence of subunit $a$ of the $\mathrm{Na}^{+}$-translocating $\mathrm{F}_{1} \mathrm{~F}_{\mathrm{O}}$-ATPase of Acetobacterium woodii: Proposal for residues involved in $\mathrm{Na}^{+}$binding. FEBS Lett. 1999, 453, 35-40. [CrossRef]

28. Rahlfs, S.; Müller, V. Sequence of subunit $c$ of the $\mathrm{Na}^{+}$-translocating $\mathrm{F}_{1} \mathrm{~F}_{\mathrm{O}}$ ATPase of Acetobacterium woodii: Proposal for determinants of $\mathrm{Na}^{+}$specificity as revealed by sequence comparisons. FEBS Lett. 1997, 404, 269-271. [CrossRef]

29. Aufurth, S.; Schägger, H.; Müller, V. Identification of subunits $a, b$, and $c_{1}$ from Acetobacterium woodii $\mathrm{Na}^{+}-\mathrm{F}_{1} \mathrm{~F}_{\mathrm{O}^{-}}-\mathrm{ATPase}$. Subunits $c_{1}, c_{2}$, and $c_{3}$ constitute a mixed c-oligomer. J. Biol. Chem. 2000, 275, 33297-33301. [CrossRef]

30. Müller, V. An Exceptional Variability in the Motor of Archaeal $\mathrm{A}_{1} \mathrm{~A}_{\mathrm{O}}$ ATPases: From Multimeric to Monomeric Rotors Comprising 6-13 Ion Binding Sites. J. Bioenerg. Biomembr. 2004, 36, 115-125. [CrossRef]

31. Rahlfs, S.; Aufurth, S.; Müller, V. The $\mathrm{Na}^{+}-\mathrm{F}_{1} \mathrm{~F}_{\mathrm{O}}-\mathrm{ATPase}$ operon from Acetobacterium woodii. Operon structure and presence of multiple copies of atpE which encode proteolipids of 8- and 18-kDa. J. Biol. Chem. 1999, 274, 33999-34004. [CrossRef] 
32. Spruth, M.; Reidlinger, J.; Müller, V. Sodium ion dependence of inhibition of the $\mathrm{Na}^{+}$-translocating $\mathrm{F}_{1} \mathrm{~F}_{\mathrm{O}}-\mathrm{ATPase}$ from Acetobacterium woodii. Probing the site(s) involved in ion transport. Biochim. Biophys. Acta (BBA) 1995, 1229, 96-102. [CrossRef]

33. Schlegel, K.; Leone, V.; Faraldo-Gomez, J.D.; Müller, V. Promiscuous archaeal ATP synthase concurrently coupled to $\mathrm{Na}^{+}$and $\mathrm{H}^{+}$ translocation. Proc. Natl. Acad. Sci. USA 2012, 109, 947-952. [CrossRef] [PubMed]

34. Thauer, R.K.; Jungermann, K.; Decker, K. Energy conservation in chemotrophic anaerobic bacteria. Bact. Rev. 1977, 41, 100-180. [CrossRef] [PubMed]

35. Müller, V. Energy conservation in acetogenic bacteria. Appl. Environ. Microbiol. 2003, 69, 6345-6353. [CrossRef] [PubMed]

36. Buckel, W.; Thauer, R.K. Flavin-Based Electron bifurcation, a new mechanism of biological energy coupling. Chem. Rev. 2018, 118, 3862-3886. [CrossRef]

37. Mock, J.; Wang, S.; Huang, H.; Kahnt, J.; Thauer, R.K. Evidence for a Hexaheteromeric Methylenetetrahydrofolate Reductase in Moorella thermoacetica. J. Bacteriol. 2014, 196, 3303-3314. [CrossRef]

38. Kremp, F.; Roth, J.; Müller, V. The Sporomusa type Nfn is a novel type of electron-bifurcating transhydrogenase that links the redox pools in acetogenic bacteria. Sci. Rep. 2020, 10, 14872. [CrossRef]

39. Wang, S.; Huang, H.; Kahnt, J.; Thauer, R.K. Clostridium acidurici electron-bifurcating formate dehydrogenase. Appl. Environ. Microbiol. 2013, 79, 6176-6179. [CrossRef]

40. Mayer, F.; Müller, V. Adaptations of anaerobic archaea to life under extreme energy limitation. FEMS Microbiol. Rev. 2014, 38, 449-472. [CrossRef]

41. Spahn, S.; Brandt, K.; Müller, V. A low phosphorylation potential in the acetogen Acetobacterium woodii reflects its lifestyle at the thermodynamic edge of life. Arch. Microbiol. 2015, 197, 745-751. [CrossRef]

42. Müller, V.; Hess, V. The minimum biological energy quantum. Front. Microbiol. 2017, 8, 2019. [CrossRef]

43. Matthies, D.; Zhou, W.; Klyszejko, A.L.; Anselmi, C.; Yildiz, O.; Brandt, K.; Müller, V.; Faraldo-Gomez, J.D.; Meier, T. Highresolution structure and mechanism of an F/V-hybrid rotor ring in a $\mathrm{Na}^{+}$-coupled ATP synthase. Nat. Commun. 2014, 5, 5286. [CrossRef] [PubMed] 